WPS 1923

Policy Research Working Paper 1923

When Vintage Technology Makes Sense

\author{
Trade policy in developing \\ countries often discriminates \\ against imports of \\ secondhand goods. Used \\ machines may make sense \\ when there is \\ complementarity between \\ skills and production \\ technologies and the skill \\ base of the importing country \\ is poor.
}

Matching Imports to Skills

Giorgio Barba Navaretti

Isidro Soloaga

Wendy Takacs

The World Bank

Development Research Group

May 1998 


\section{Summary findings}

Trade policies in many developing countries discriminate - through import bans, licensing requirements, or higher tariff rates. Even Australia adds a $\$ 12,000$ tariff on used cars. Such discrimination is often motivated by the desire to protect domestic industries from competition from low-priced goods, to avoid becoming a dumping ground for castoffs from high-income countries, or to push domestic industries toward the technological frontier.

But trade restrictions on used capital goods may be inappropriate in countries where low wages and high interest rates call for labor-intensive production processes. Older equipment is likely to be more laborintensive than new equipment, because technological changes tend to be labor-saving and older equipment requires greater maintenance and presents greater risk of machine downtime.

In this empirical analysis of international trade in production machinery, Barba Navaretti, Soloaga, and Takacs examine choices between new and used equipment, when there is labor-saving technical progress and the skills and technology available in a firm complement each other. They examine U.S. exports of metalworking machine tools by country of destination, classifying machines by vintage technological characteristics. They do so by developing a new method for classifying trade data on machines according to the minimum technological skills necessary to operate them. They are consequently able to use trade data to measure technology transfer. The main findings:

- The lower a country's level of development - as measured by such indicators as per capita income, wages, and average education - the greater the share of used equipment imported by the country.

- Imports of used machinery are greater, the faster the technical change and the greater the skills required to run the machinery efficiently.

They conclude that technological factors and skill constraints may be far more important than wage and interest-rate differentials in determining a firm's choice of technique in developing countries. Consequently the technological gap between advanced and developing economies rises when machines embody faster technological progress.

Barba Navaretti, Soloaga, and Takacs argue against constraints on imports of used equipment, not for the reason often given in existing literature - inappropriate capital-labor ratios in low-wage countries - but because investing in advanced technologies makes sense only if the countries importing them have the skill to use them.

This paper - a product of the Development Research Group - is part of a larger effort in the group to assess the role of trade barriers on technology diffusion. Copies of the paper are available free from the World Bank, $1818 \mathrm{H}$ Street NW, Washington, DC 20433. Please contact Lili Tabada, room MC3-333, telephone 202-473-6896, fax 202-522-1159, Internet address ltabada@worldbank.org. The authors may be contacted at barba@imiucca.csi.unimi.it, wtakacs@umbc2.umbc.edu, and isoloaga@worldbank.org. May 1998. (33 pages)

The Policy Research Working Paper Series disseminates the findings of work in progress to encourage the exchange of ideas about development issies. An objective of the series is to get the findings out quickly, even if the presentations are less than fully polished. The papers cary the names of the authors and should be cited accordingly. The findings, interpretations, and conclusions expressed in this paper are entirely those of the authors. They do not necessarily represent the view of the World Bank, its Executive Directors, or the countries they represent. 


\title{
When Vintage Technology Makes Sense \\ Matching Imports to Skills
}

\author{
Giorgio Barba Navaretti \\ (Universita' degli Studi di Milano \\ Centro Studi Luca d'Agliano and Fondazione Eni Enrico Mattei) \\ Isidro Soloaga \\ (World Bank and University of Maryland, College Park) \\ Wendy Takacs \\ (University of Maryland, Baltimore County and World Bank)
}

This paper was prepared while the first author was a visiting researcher at the International Trade Division, International Economics Department, World Bank. Fondazione Eni Enrico Mattei and Centro Studi Luca d'Agliano have partly funded this project. Anthony M. Bratkovich, Engineering Director, U.S. Association for Manufacturing Technology, was extremely patient and helpful in leading the authors through the mysteries of the technological characteristics of metalworking machines. Gabriel Castillo, James Tybout, Maurice Schiff, John Nash, Garry Pursell, and an anonymous referee gave very useful suggestions. The authors also thank Jennifer Ngaine and Jeff Hayden for help with tables and charts. 


\section{Contents}

1. Introduction

2. New versus used machines

3. The firm's choice of new versus used machines

4. Demand for used equipment with heterogeneous firms

5. The empirical analysis: determinants of trade in used equipment.

6. Conclusions 


\section{Introduction}

Many developing countries design their trade policies to discriminate against importation of second-hand goods through import bans, licensing requirements, or higher tariff rates. Discrimination against used products is even found among the ranks of the industrialized countries; witness Australia's additional $\$ 12,000$ tariff on used cars. ${ }^{1}$ The motivation for these policies is a combination of a desire to protect domestic industries from competition from low-priced goods, an attempt to avoid becoming a "dumpingground" for cast-offs from high-income countries, and an attempt to push industries toward the "technological frontier" and avoid the use of "obsolete" technologies.

But trade restrictions on used capital goods appear contrary to the appropriate choice of production techniques in developing countries, where low wages and high interest rates would call for the use of labor-intensive production processes. Older equipment is likely to be more labor-intensive than new equipment because technological change tends to be labor-saving and older equipment requires greater maintenance and implies greater risk of machine down-time. Moreover, the smaller optimal scale of older machines may be more appropriate to smaller developing-country markets and older machines may be more flexible in their use and less specialized. Some or all of these considerations led a number of authors ${ }^{2}$ to conclude that firms in low-wage developing countries would find

\footnotetext{
${ }^{1}$ Wonnacott, Paul. (1994) "The Automotive Industry in Southeast Asia: Can Protection Be Made Less Costly?" mimeo, Institute for International Economics, Washington, D.C., September, p. 2.

2 See Sen (1962), Schwartz (1973), James (1974), Thoumi (1975) and Mainwaring (1986).
} 
second-hand equipment more profitable than new machines and that developing countries would suffer a welfare loss from import restrictions on used machinery.

In this literature some models have focused on the impact of greater maintenance costs as machines age (Schwarz (1974), Thoumi (1975)), the so-called "vintage capital" literature has emphasized labor-saving technological change (Bardhan (1970), Smith (1976)), and some models have incorporated both these phenomena (Mainwaring (1986)). Recent contributions on technology transfer link the choice of technique to "skills" available to a firm or in a country. Such "skills" are human capital or other technological capabilities acquired through deliberate learning and/or learning-by-doing (Benhabib and Rustichini (1991), Chari and Hopenhayn (1991), Keller (1994), Javanovic and McDonald (1993) and Javanovic and Nyarko (1995 and 1996)). The more skills that are specific to a particular technique, the more costly it is to switch to that technique. The skill factor is likely to affect the choice between new and used machines, when new models also embody technical change.

In this paper we model a firm's choice between new and used machines and test the predictions emerging from the modeling exercise using data on U.S. exports of new and used metalworking machinery, disaggregated by type of machine and by country of destination. The model incorporates the three factors mentioned above: greater downtime as machines age; labor-saving technical progress; and skill requirements of more technologically sophisticated machinery.

We use as a basic framework for analysis a model of trade in used machines among 
heterogeneous firms. Most of the literature on trade in used machinery focuses on heterogeneity between countries based on the stylized fact that developing countries are characterized by lower wages and higher capital costs than industrialized countries (Sen, 1962; Smith, 1974; Mainwaring, 1986). We adopt a slightly different approach by adopting a model based on heterogeneity among firms (as in Bond (1983)). The model takes into account that if labor and capital markets are imperfect, different firms may face different wage rates and capital costs. Firms can also differ in the technical and managerial skills available to them. Heterogeneity among firms located in different countries provides the underlying motive for international trade in new and used capital equipment. Models that do not take firm heterogeneity into account predicted rather extreme trade patterns in used machinery. For example, several models predict that firms in developing countries would import only the oldest available machinery. The assumption that firms in developing countries are heterogeneous in that they may face different wage structures and interest rates is reasonable given imperfections in capital markets, the co-existence of multi-nationals and purely domestic firms, and the dichotomy between formal and informal sectors.

The next section explores the factors influencing machine choice. Section 3 models the firm's choice between used and new machines. Section 4 extends the results on firm choices to a broader country context. Section 5 develops the empirical analysis. Section 6 presents conclusions. 


\section{New versus used machines}

New and used machinery can differ in three important ways: risk of breakdown; productivity of embodied technology; and required technical skills.

\section{Risk of downtime}

Used machinery normally requires more maintenance and is more likely to break down. Maintenance requires high labor input. In addition, if workers are paid for a regular work schedule, machine "down-time" implies idle workers, which implicitly increases the labor-intensity of the production process. The impact of breakdowns and maintenance requirements of used machines are captured by adjusting output for downtime using the factor $\alpha$, defined as the ratio of a used machine's output to that of an identical new machine $(0<\alpha<1)$.

\section{Labor-saving technical progress}

Machinery of a given vintage embodies the technology available when the machine was produced. Labor-saving technical progress is captured by distinguishing between output per worker with a machine newly produced in the current period $\left(a_{n}\right)$ and output per worker in a machine embodying last-period's technology when that machine was 
new $\left(a_{0}\right)$. Thus the ratio $a_{0} / a_{n}$ captures the rate of labor-saving technical progress, independent of the downtime effect $\alpha$, with $\left(a_{0} / a_{n}\right) \leq 1$.

To clarify the independent impacts of technical progress and the aging process in the context of metalworking machines, the object of the empirical analysis of this paper, it is useful to distinguish between "low-tech" and "high-tech" machines. From a technological point of view, machine tools (especially metal cutting ones) can be divided into two broad categories. Numerically controlled machines have a fast rate of technological upgrading, linked to the development of electronics. Manual machines may improve in terms of design and safety conditions, but have a virtually nil rate of technical progress. "Low-tech" machines are those for which there is no technical progress and "high-tech" machines are those for which the technology is constantly improving with time. The difference in labor productivity between new and used low-tech machines is attributable to increases in maintenance and longer run-down time alone. The difference in labor productivity between new and used high tech machines is attributable to both technical progress and increases in maintenance and longer run-down time.

Figure 1 illustrates labor productivity associated with machines of different vintage, with and without technical progress. For low-tech (manual) machines output per worker varies with age along the straight line LL due to the down-time effect (the $\alpha$ effect). For high-tech (numerically controlled) machines, labor productivity declines with age along curve HH because of the combined effect of down-time and the lower technological sophistication embodied in older machines. Note two key features of the 
relationships in Figure 1. First, output per worker is always lower for low-tech than for high-tech machines. Second, at any point in time, the decline in labor productivity with age is larger for high-tech machines than for low-tech ones.

Figure 1. Labor saving and machine age with and without technical progress.

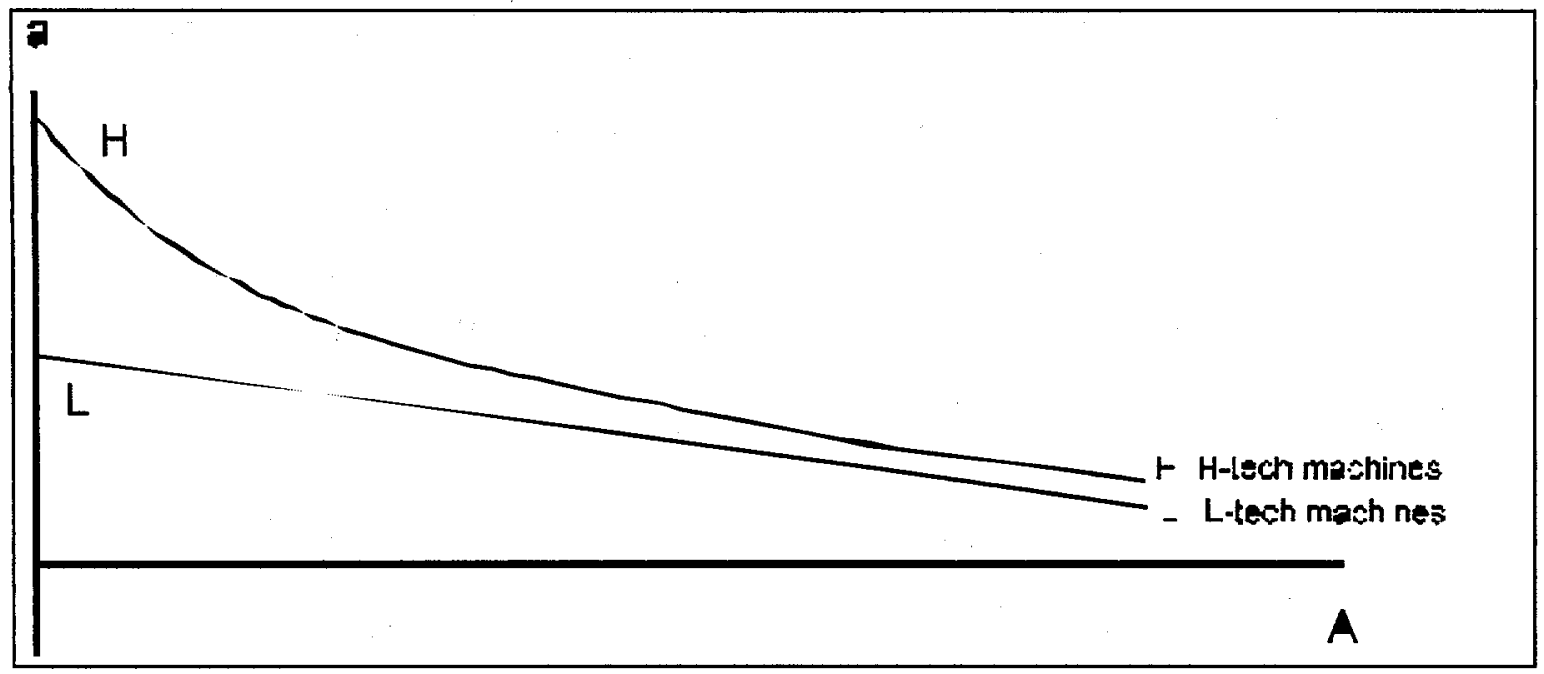

Skill factors

The literature on vintage technology emphasizes the role of technology specific skills. Different technologies may require completely different skills (Evenson and Westphal, 
1994; Keller, 1994). Metal working machine tools provide a very good example. Manual machines (low-tech) require sophisticated craftsmen to operate them (skills in the hands). Numerically controlled machines (high-tech), require electronic technicians (skills in the head). Accumulated "learning by doing" could be lost when a firm switches to a new technology (Chari and Hopenhayn, 1991; Dasgupta and Stiglitz, 1988, Jovanovic and MacDonald, 1993; Jovanovic and Nyarko, 1995 and 1996). Complementarities between workers with different skills may constrain the choice of technology (Chari and Hopenhayn, 1991).

Linking the education level of the people using the machines (craftsmen, technicians, engineers) to the technology embodied in the machines is essential, but not sufficient. Technological knowledge is often tacit and not transmittable in a codified form (David, 1993), and 'technological capabilities' are related to the performance of many different technological functions (Lall, 1987). Skills should therefore refer to the 'absorption capacity' of a firm or a country, i.e. the ability to master a given technology (Evenson and Westphal, 1994; Keller, 1994). Absorption capacity is affected by a broad set of factors pertaining to the physical, social and economic characteristics of a firm or a country.

Firms may therefore be reluctant to move to high tech technologies, because they do not have the skills to use them, or because building up such skills would be more costly than continuing to use low-tech machines. In our simplified setting, we assume that the adoption of a new high tech technology by a firm which has not the appropriate skills to 
run it entails a loss in productivity. The productivity level with current skills is captured by $\gamma$, the proportion of full capacity output achievable with new machines, given current skills (where $0 \leq \gamma \leq 1$ ). We refer to $\gamma$ as the "inability coefficient", where $\gamma$ is lower the less able the firm. The skill factor may constrain the choice between new and used machines, as far as new machines embody an increasing level of technological sophistication.

Trade Policy

Different trade policy instruments influence the choice between new and used machines in different directions. An equal ad valorem tariff rate $t$ on all imported machines raises the domestic price of new and used machines proportionally. Restrictions discriminating against used equipment through either higher tariffs or licensing restrictions will increase the cost of used equipment disproportionately and discourage its use.

\section{The firm's choice of new versus used machines}

Assume that machines last for two periods. A firm buying a new machine can sell it at the end of the period for the going price of a used machine, but used machines will have zero scrap value at the end of the second period of use. At the end of the period, 
the firm's (net) costs using a new machine embodying the current period's technology would be $\mathrm{b}^{3}$ :

$$
C_{n}=P_{n}(1+r)(1+t)-P_{u}(1+t)+\frac{w}{a_{n}} q
$$

and with a machine embodying the previous period's technology (if the machine had never been used) would be:

$$
C_{o}=P_{o}(I+r)(I+t)+\frac{w}{a_{o}} q
$$

where: $C_{i}=$ total cost of production using machinery $\mathrm{i}$

$P_{i} \quad=\quad$ price of machine $i$

$\mathrm{a}_{\mathrm{i}}=$ labor productivity of machine $\mathrm{i}\left(=\mathrm{q}_{\mathrm{i}} / \mathrm{L}_{\mathrm{i}}\right)$ when it is new

$\mathrm{L}_{\mathrm{i}} \quad=\quad$ labor units per time period with machine $\mathrm{i}$

$\mathrm{w}=$ wage rate per time period

$r=$ interest rate

$\mathrm{t}=$ ad valorem tariff rate on machinery imports

$\mathrm{q}=$ full capacity output of a machine when it is new ${ }^{4}$

If the machine embodying last period's technology has been used in the previous period, it yields only $\alpha$ of the output it did when new, and if the productivity of new machinery is constrained due to lack of skill in the labor force, the new machine yields only $\gamma$ times the designed output. More precisely:

$\begin{array}{cll}\operatorname{archine} & =\quad \text { output of } 1 \text { period old machine/output of identical new } \\ \gamma & =\quad \begin{array}{l}\text { proportion of full-capacity output of new machine achievable } \\ \text { with current skills }\end{array}\end{array}$

3 It is assumed that machines are paid at the beginning of the period and wages at the end of the period. 4 Note that we assume that full capacity output of a new machine is always the same (q) independently of machine type, whereas the labor input necessary to achieve full capacity output changes (thus affecting labor productivity $\mathrm{a}_{\mathrm{i}}$ ) 
Letting $C_{u}$ and $P_{u}$ denote, respectively, production costs with, and the market price of, a machine that embodies the previous period's technology that has been used for one period, a firm will be indifferent between new and used machinery if unit costs are the same with the two types of equipment:

$$
\frac{C_{n}}{\lambda q}=\frac{C_{u}}{\alpha q}
$$

Thus the firm would be indifferent between new and used equipment when:

$$
\frac{\left(P_{n}(1+r)-P_{u}\right)(1+t)+\frac{w}{a_{n}} q}{\gamma}=\frac{P_{u}(1+r)(1+t)+\frac{w}{a_{o}} q}{\alpha}
$$

Solving for $\mathrm{P}_{\mathrm{U}}$ yields $\mathrm{U}^{*}$, the price of used equipment at which the firm would be indifferent between using new and used equipment:

$$
\begin{gathered}
U^{*}=\frac{\alpha P_{n}-\gamma \beta\left(1-\frac{\alpha a_{o}}{\gamma a_{n}}\right) \frac{w q \theta}{a_{o}}}{\gamma+\alpha \beta} \\
\text { where: } \begin{array}{rll}
\beta & = & 1 /(1+\mathrm{r}) \\
\theta & = & 1 /(1+\mathrm{t})
\end{array}
\end{gathered}
$$

If a firm's indifference price (Ui) is above the market price of used machinery $\left(\mathbf{P}_{\mathbf{u}}\right)$, the firm will buy used equipment; if $U_{i}<P_{u}$ firms will opt to buy new equipment. Given the market price $P_{u}$, an increase in $U^{*}$ makes it more likely firms will buy used 
equipment and a decrease in $\mathrm{U}^{*}$ increases the chance they will buy new equipment.

Note a number of implications of equation (5):

- The indifference price of used machines equals the price of new machines with production capacity equal to that of used machines (the first term in the numerator in the RHS of (5)), net of the higher labor costs of used versus new machines (the second term in the numerator in the RHS of (5));

- Holding other things equal, the gap between the price of new machines and the indifference price of used machines will be larger the greater the rate of technical progress (the smaller $a_{0} / a_{n}$ ).

- Ceteris paribus, the smaller is $\alpha$ (the more use of equipment generates a loss in productivity) and the smaller is $\left(a_{0} / a_{n}\right)$ (the greater the rate of labor saving technical progress) the lower the indifference price (the less desirable are used machines).

- The indifference price of used machines ( $\left.\mathrm{U}^{*}\right)$ increases as $\gamma$ falls ceteris paribus, so firms that do not have the technical skills required by new machinery will be more likely to opt for used equipment.

The impact of the wage rate, interest rate, and machinery tariff rate on the indifference price of used machinery is more complicated and depends crucially on the firm's skill level, $\gamma$.

Unless the firm is very lacking in skills needed to use higher technology equipment, the productivity of new machines is greater than used machines for the firm i.e. 
$\left(\alpha a_{u} / \gamma a_{n}\right)<1 . \quad$ In this case $U^{*}$ declines when $w$ and $\beta$ increase, so firms facing high wages and a low cost of capital are more likely to prefer new machines (as $\mathrm{U}^{*}<\mathrm{Pu}$ is a more likely event). Also, $U^{*}$ decreases as $\theta$ increases, implying that higher tariffs raise the indifference price of used machines, making their purchase more likely. Indeed, the impact of a tariff is just like that of the cost of capital $r$. But lack of skill to make use of higher technology equipment (low $\gamma$ ) could switch the direction of or eliminate the influence of wages, interest rates and the tariff level on the indifference price.

\section{The Market for Used Machines}

Assume for the moment that there are two regions, North and South and that firms within a region are homogeneous (have the same $\gamma$ ), and face the same factor prices. Northern firms have higher $\mathrm{w}$ and $\gamma$, and lower $\mathrm{r}$ than Southern firms. Assume that the South is small in machinery markets compared to the North so the South is a price taker; it faces an infinitely elastic supply of used machines at the indifference price of used machines in the North. Given that the South has lower wages, higher interest rates and more limited technical skills, the indifference price of Southern firms will exceed that of Northern firms (from (5)). Thus, with homogeneous firms the South would only buy used machines, and the North would buy both new and used ones.

Southern demand for used machines must be consistent with the zero profit condition:

$$
P_{u}=\left[\alpha P(x)-\frac{w_{s}}{a_{o}}\right] q \beta_{s} \theta_{s}
$$


(6)

where: $\mathrm{x}=$ quantity of the final product produced and sold by the South $P_{x}(x)=$ price of $x$

subscript $\mathbf{s}$ designates value of the variable in the South

The production function is given by:

$x=\alpha q Q_{u}$

where: $Q_{u}=$ quantity of used machines employed by the South

The demand function for good $\mathrm{x}$ is given by:

$P(x)=b-c x$

Substituting (7) into (8) and (8) into (6) yields the demand function for used machines:

$P_{u}=\left(\alpha b-\frac{w_{s}}{a_{o}}\right) q \beta_{s} \theta_{s}-c \alpha^{2} q^{2} \beta_{s} \theta_{s} Q_{u}$

When $P_{u}>U^{*}$, i.e. when the price of used equipment is larger than the indifference price of Southern firms, the latter will not buy any used machines. Thus, the inverse demand function (9) must be consistent with the following condition:

$$
P_{u} \geq U^{*} \text { when } Q_{u}=0 \text {. }
$$


Therefore:

$P_{u}=U^{*}{ }_{s}-c \alpha^{2} q^{2} \beta_{s} \theta_{s} Q_{u}$

In equilibrium, as the North is large and pins down the price for used equipment, the quantity of used equipment demanded by the South will be the quantity demanded at the North's indifference price $\left(U^{*}\right)$. Equating (10) and (5) (for the North) yields the equilibrium quantity of used machines demanded by a Southern firm:

$$
Q_{u}=\frac{U^{*}{ }_{s}-U_{n}^{*}}{c \alpha^{2} q^{2} \beta_{s} \theta_{s}}
$$

Equation (11) shows that the larger is the gap between the indifference prices of Southern and Northern firms, the larger will be the quantity of used machines demanded in the South. This result can be understood more clearly by looking at the graphic representation of the market for used machines in figure 2 below. The equilibrium quantity of used machines will depend upon the interaction between the Northern indifference price, $\mathrm{U}^{*}{ }_{\mathrm{n}}$ which defines supply $\mathrm{NN}$, and Southern demand SS (equation $10)$. 


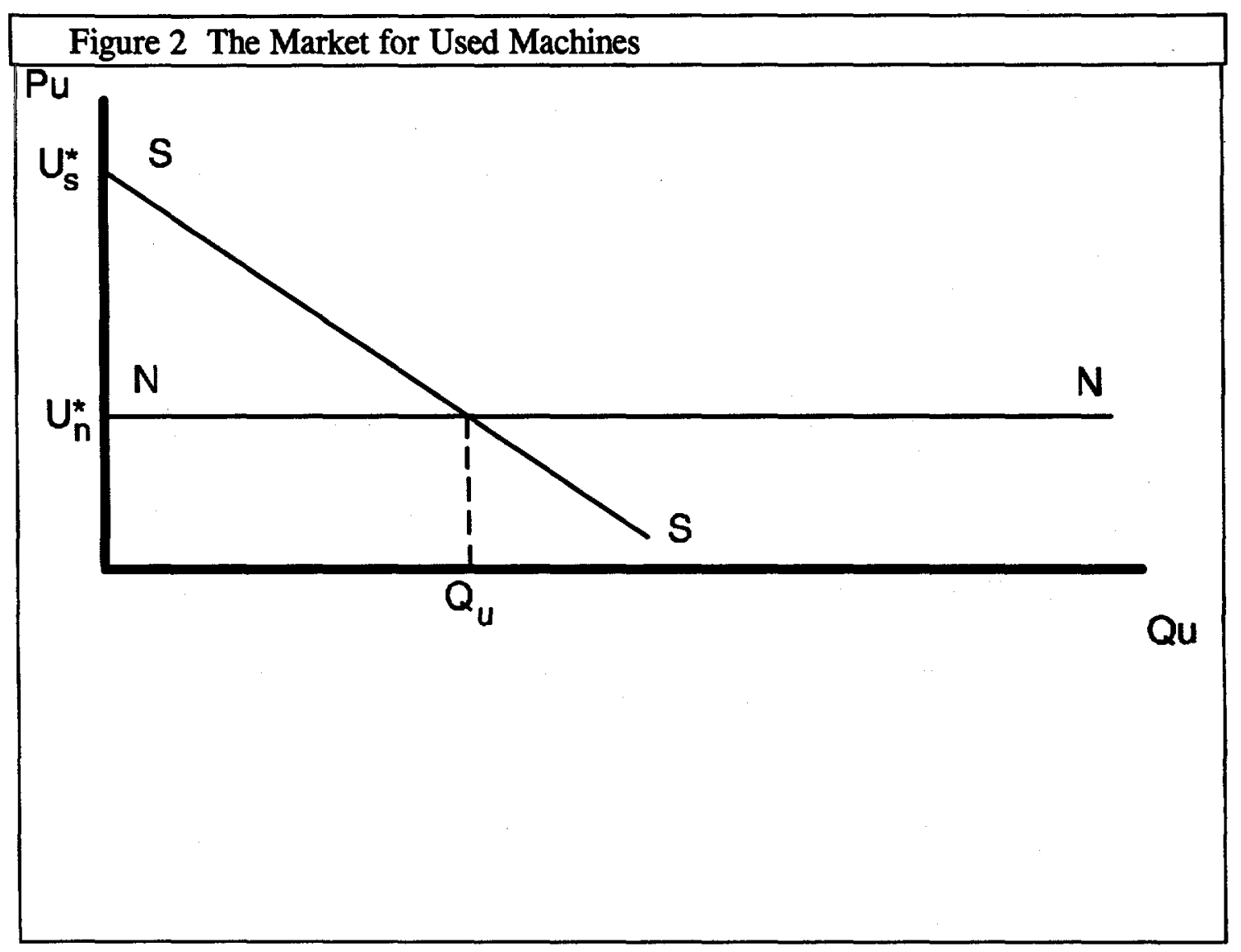

When the gap between indifference prices increases, the shift in SS and NN generates an increase in the quantity of used machines demanded by the Southern firm. From (5) we can gather how the different components of the indifference prices affect changes in demand.

First, Southern purchases of used machines increase with technical progress (the ratio $\left.a_{0} / a_{n}\right)$. Indeed, the larger technical progress between new and used equipment, the larger the $\mathrm{U}^{*}{ }_{\mathrm{s}}-\mathrm{U}^{*}{ }_{\mathrm{n}}$ gap for any given difference in factor prices. An increase in technical progress lowers indifference prices of both Northern and Southern firms. 
Both NN and SS shift downwards, but because of lower wages in the South, the Southern indifference price declines less than the Northern and the equilibrium quantity of used equipment demanded in the South increases. One implication of this result is that faster technical progress (smaller $a_{0} / a_{n}$ ) will increase the technological gap between Northern and Southern capital stocks.

Second, the net effect of an increase in the downtime caused by used machines (a decline in $\alpha$ ) is ambiguous. The effect on the indifference prices is the same as the one caused by technical progress: both SS and NN shift downwards, but SS less than NN. However, SS also becomes steeper, as the Southern firm will demand fewer machines at any given price.

Third, a lower $\gamma$ (the less skilled the labor force) in the South implies a higher Southern indifference price and therefore a larger demand for used machines. Indeed, the increase in productivity of new machines will be offset by the lack of appropriate skills to use them.

Fourth, factor prices affect the equilibrium quantity of used machines in the expected directions. A relative increase in Northern wages lowers the Northern indifference price and increases the quantity of used machines demanded by the South. Indeed, the price of used machines would decline more than Southern returns from used machines. The opposite happens for a relative increase in Southern wages. For the same reason, a decline in Northern interest rates increases the equilibrium quantity of used machines bought by the South. 


\section{Demand for used equipment with heterogeneous firms}

Until now we have assumed that all firms within each region are identical, which implies that their indifference prices would be the same. But labor and capital market imperfections would imply that firms may face different wage and interest rates and may have widely different values of $\gamma$. These differences are likely to be particularly severe in developing countries, given credit rationing, labor regulations, dichotomies between formal and informal sectors and the coexistence of multinational and indigenous firms.

We therefore modify the above analysis to take into account heterogeneity among firms in the South. Heterogenous firms imply that there will be a distribution of indifference prices around an average that will be higher than the indifference price in the North. If we keep the assumption that used machinery prices are determined in the North, then heterogeneity of firms implies that each Southern country may import a variety of both new and used machines, and that corner solutions in which countries import either all new or all used machines will be pure exceptions. To understand this point it is useful to discuss figure 3 below. 
Figure 3. Demand for used machines by Southern firms

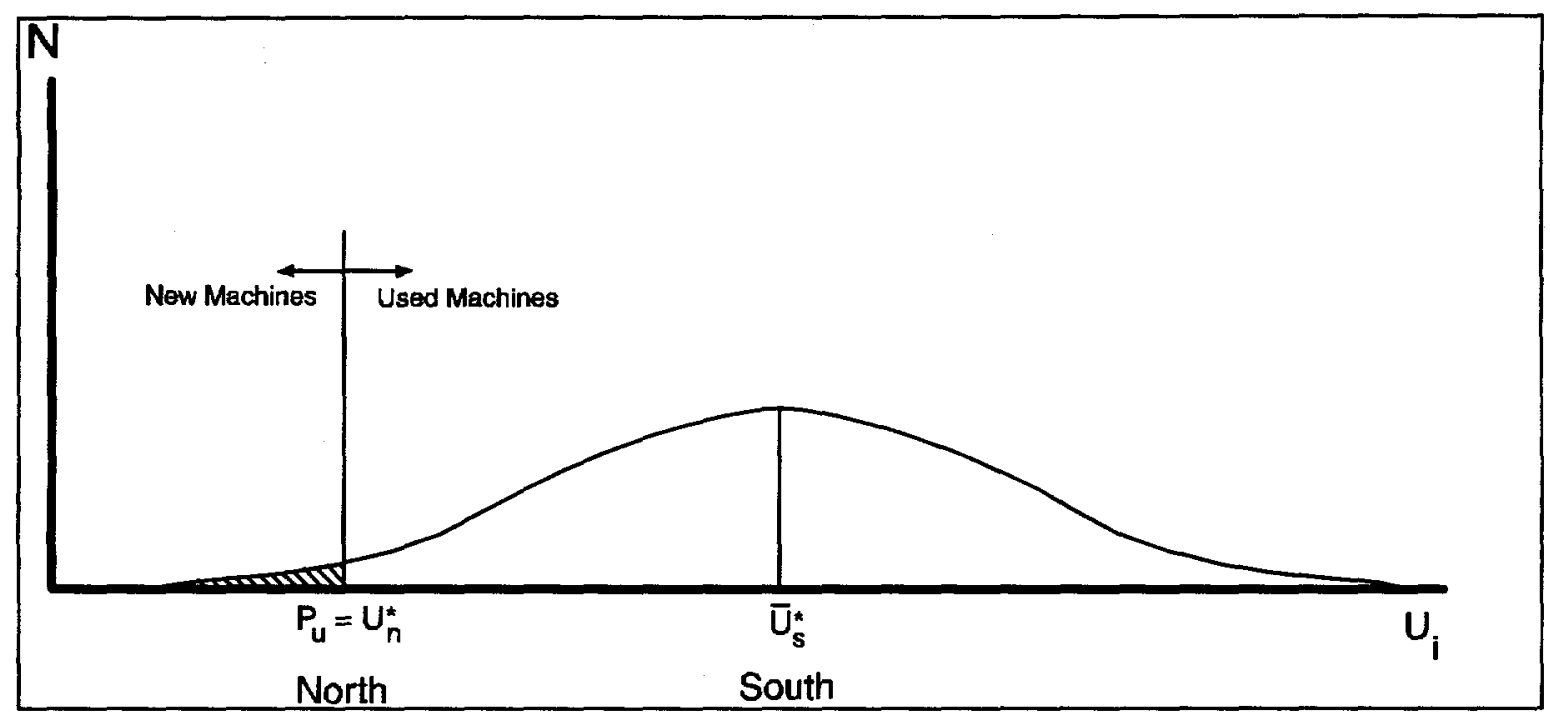

$U^{*}$ is the indifference price of Northern firms, which determines the price of used machinery $\mathrm{P}_{\mathrm{u}} \cdot \overline{\mathrm{U}}_{s} *$ is the indifference price of the average Southern firm. $\mathrm{N}$, on the vertical axis, is the number of firms. All firms with $U^{*}{ }_{i}>U^{*}{ }_{n}$ will buy used machines and all firms with $U{ }^{*}<U^{*}{ }_{n}$ will buy new machines. The majority of Southern firms will buy used machines, but a number of them will have an indifference price which is lower than the one of the average Northern firm, and they will therefore buy new machines.

The quantity of used machines demanded will depend on the distance between the North and average South indifference price and on the shape of the distribution. The 
larger the distance, the larger the share of Southern firms purchasing used machines. As long as the determinants of indifference prices remain the same, heterogeneity among firms does not disturb the predictions in the previous sections, but does allow for non-corner solutions in which Southern countries import some new and some used machinery.

\section{The empirical analysis: determinants of trade in used equipment.}

In this section we apply the model developed above to data on U.S. exports. U.S. export data on some types of vehicles, equipment and machinery are sufficiently disaggregated to distinguish between new and used goods. Here we concentrate on U.S. exports of metalworking machine tools between 1990 and 1994, disaggregated by commodity classification, new versus used, and country of destination. The sample covers 38 types of metalworking machines, aggregated to the 6 -digit level in the Harmonized System, and exports to 23 importing countries.

Different types of metal working machine tools require different types of skills. Manual machines are operated by skilled workers or craftsmen. Numerically controlled machines are operated by both technicians and unskilled workers. Machining centers are even more complex and require higher-level technicians and engineers. Furthermore, machines with higher skill requirements also tend to have a 
faster rate of technological change. Thus, firms upgrading from manual to numerically controlled machines must change their skill endowment. This probably explains why only $25.2 \%$ of new investments in machine tools in the US carried out between 1985 and 1989 where in numerically controlled machines, although American manufacturers started investing in these type of machines in the early 1970s. (Oliner, 1993).

With the guidance of an engineer intimately familiar with the complexities and skill requirements of each type of machine, we developed a "skill index" for each 10-digit export category, reflecting the degree of skill required in the labor force to operate that type of machine. The value of the index ranges from 1 to 4 , increasing with the level of skills required to use the machine. The specific skills associated with the index are reported in table 1 :

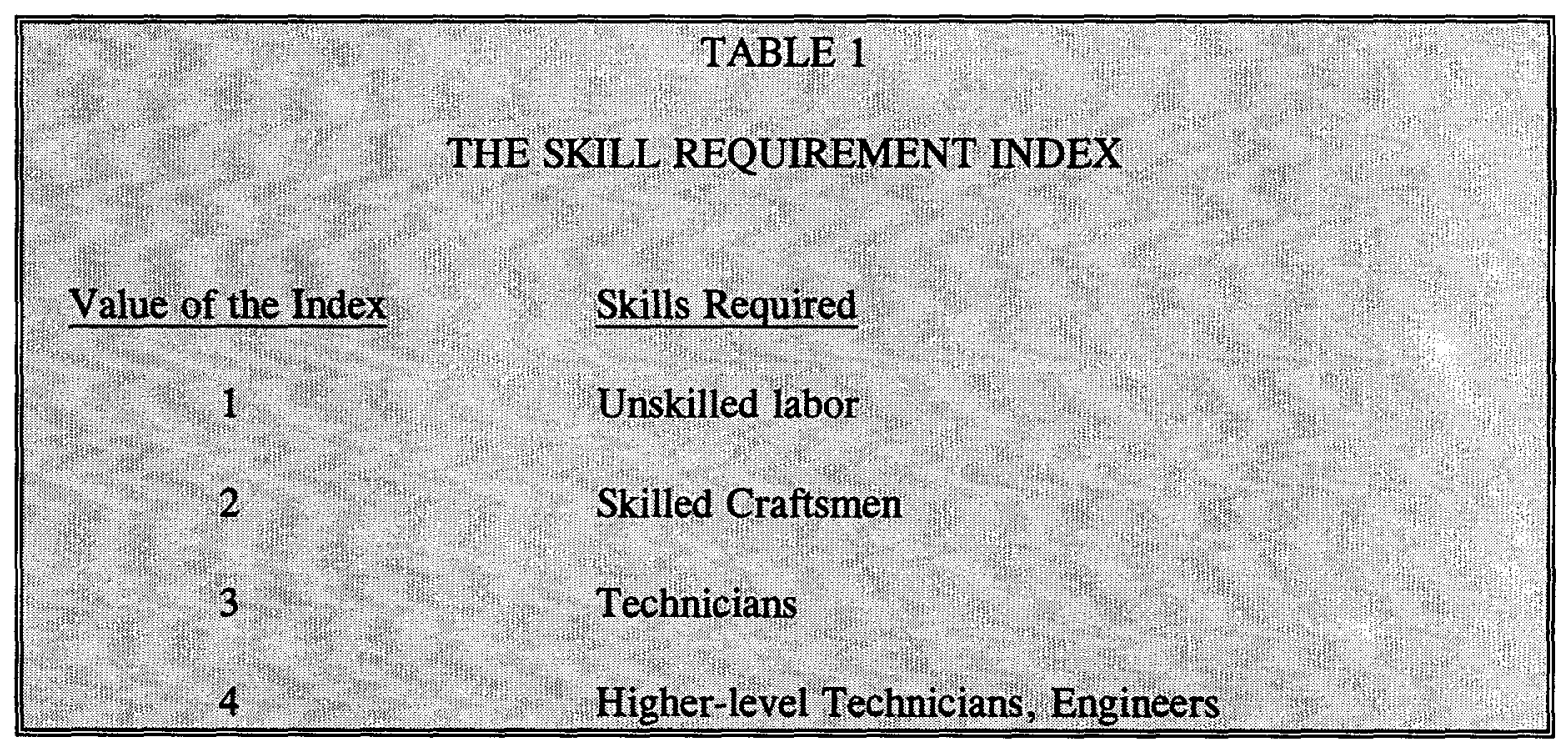


Basic statistics on U. S. exports of new and used machine tools to low-, middleand high-income countries are reported in table 2. The first column shows the shares (by quantity) of used machinery in total imports of machinery from the United States. As expected, low-income countries import a higher ratio of used to new machinery, but the variation in the shares of machines imported second-hand (between roughly 10 percent for high-income countries and about 24 percent for low-income countries) is not huge. The average skill index of imported machinery is higher for high-income countries than low-income countries, but again the difference is not large. If we divide machines into "high-tech" (skill index 3 and 4) and "low-tech" (skill index 1 and 2), the same pattern emerges; The ratio of used machines to new machines imported is greater for low-income countries than for high-income countries. Note also that the share of equipment imported second-hand is larger for high-tech machines than for low-tech ones.

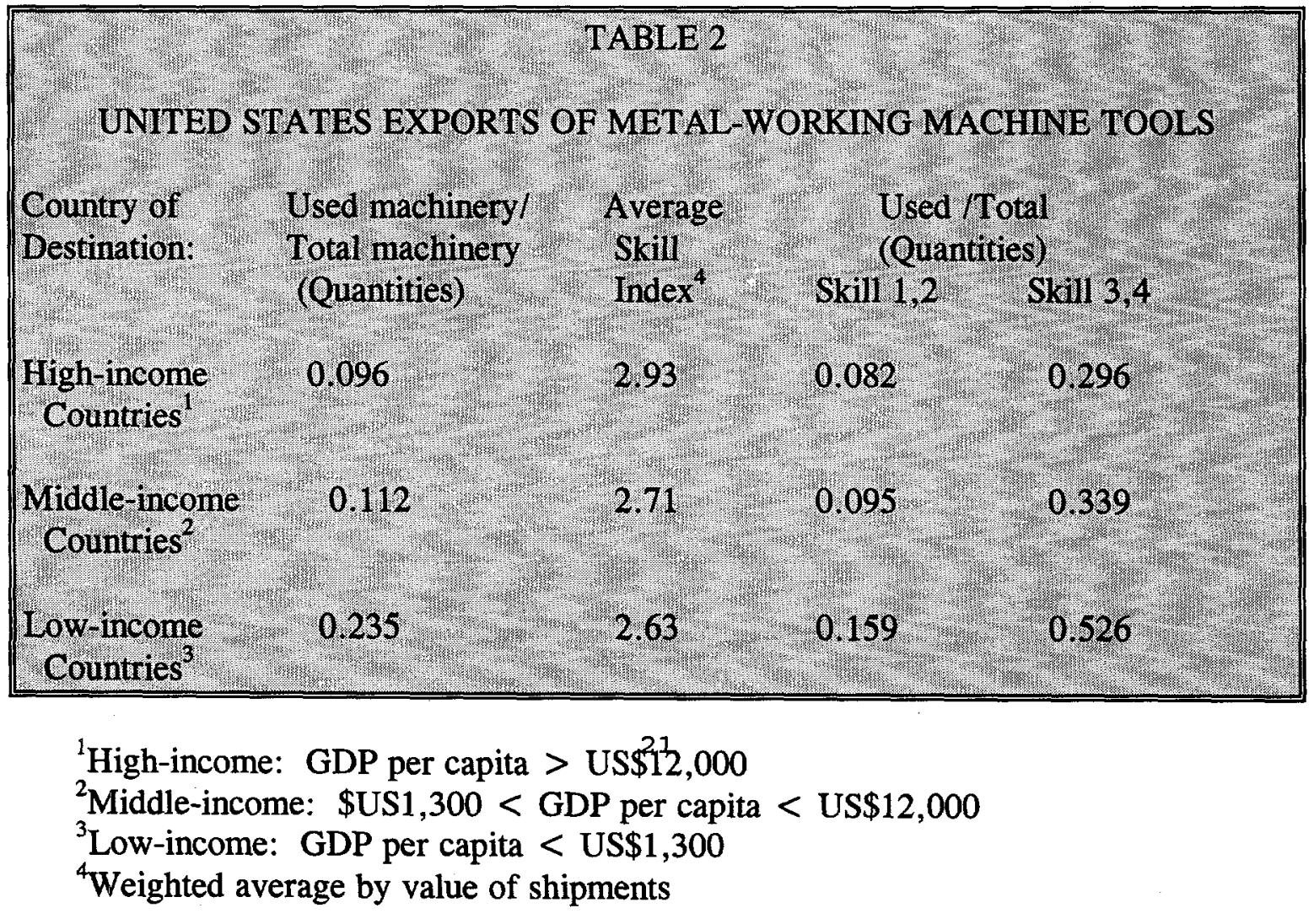


These figures provide some empirical support for our hypotheses on trade in used equipment, but it does not provide information on which of the many factors cited are significant in determining the choice between new and used machines. To cast some light on this question we undertook econometric analysis of the data to try to explain the new/used equipment choice.

We estimated the share of used machinery in total U.S. exports of each machine category to each importing country as a function of importing-country-specific variables (wage rates, skill levels, and trade barriers) and machine-specific variables (rate of technical progress of the type of machinery and skill level required to operate it). The basic estimating equation was:

$$
Q_{i j}^{u}=\alpha_{0}+\alpha_{1} w_{j}+\alpha_{2} T_{i j}+\alpha_{3} S_{i j}+\alpha_{4} E_{j}+\alpha_{5} N_{j}+\alpha_{6} t_{i j}+v_{i j}
$$

where: $\quad Q_{i j}^{u}=\quad$ quantity of used machinery of type $i$ exported to country $j$ as a proportion of total machinery of type $i$ imported by country $j, 1990-$ 1994

$\mathbf{w}_{\mathrm{j}}=\mathbf{a}$ factor-price variable (wage/interest rate ratio; wage rate in U.S. dollars; or

GDP per capita in U.S. dollars) in country $j$

$T_{i j}=$ rate of technological progress in machinery of type $\mathrm{i}$ imported by country $j$, measured as the difference of unit values of new and used machinery

$\mathrm{S}_{\mathrm{ij}}=$ average skill requirement index for machines of type $\mathrm{i}$ exported to country $\mathbf{j}$

$E_{j}=$ education level in country $j$, measured by average years of school

$\mathrm{N}_{\mathrm{j}}=$ dummy variable $=1$ if country $\mathrm{j}$ had a non-tariff barrier on imports of used equipment during 1990-1994, 0 otherwise 


$$
\begin{aligned}
& t_{i j}=\text { tariff rate on imports of machinery of type } i \text { in country } j \\
& v_{i j}=\text { disturbance }
\end{aligned}
$$

The dependent variable $\left(Q_{\mathrm{ij}}^{\mathrm{u}}\right)$ is the share of the total amount of each machinery type each importing country imported second-hand during the period 1990 through 1994. Completely consistent trade data for new and used machinery are only available back through $1990 .^{5}$ Because many country-specific variables were not available for all of these years, we worked only with machine and country specific observations by aggregating the 5 years, using total U.S. exports of each commodity classification to each country 1990-1994 for the trade flows and averaging observations on the other variables across the five years, or over the largest number of years for which we had observations. Further details on the variables used and data sources appear in the Data Appendix.

The results are presented in table 3 . We estimated three versions of the model using three different measures for the factor-price variable. Equation 1 uses the ratio of the wage rate to the interest rate; equation 2 the wage rate in U.S. dollars, and equation 3 per capita GDP in U.S dollars. Initial estimates using the OLS estimation method (not reported) posed heteroskedasticity problems, as the variance of the error term is decreasing with the share of imports of machines of type $i$ on total imports of country $j$. Indeed, the lower the share, the less stable are imports of a given machine. We corrected for heteroskedasticity using two methods. The first (equations 1a,2a,3a) was a Weighted Least Square method, using the share of imports of machines of type $i$ on total imports of

\footnotetext{
${ }^{5} \mathrm{~A}$ reclassification of the export data in 1990 created a break in the series, so although data on used machinery exports are available for previous years, the data are not based on exactly the same commodity classifications.
} 
country $j$ as weights. Because there are potential endogeneity problems with this method that risk introducing spurious correlation, we 
TABLE 3

DETERMINANTS OF IMPORTS OF USED MACHINERY

\begin{tabular}{|c|c|c|c|c|c|c|}
\hline & $\begin{array}{c}\text { la } \\
\text { weighted ols }\end{array}$ & $\begin{array}{c}\text { lb } \\
\text { White }\end{array}$ & \begin{tabular}{c|}
$2 \mathrm{a}$ \\
weighted ols
\end{tabular} & $\begin{array}{c}2 b \\
\text { White }\end{array}$ & $\begin{array}{c}3 a \\
\text { weighted ols }\end{array}$ & $\begin{array}{c}3 b \\
\text { White }\end{array}$ \\
\hline \begin{tabular}{|c|} 
Number of \\
observations
\end{tabular} & $\mathrm{N}=228$ & $\mathrm{~N}=228$ & $\mathrm{~N}=324$ & $\mathrm{~N}=324$ & $\mathrm{~N}=354$ & $\mathrm{~N}=354$ \\
\hline constant & $\begin{array}{c}0.421 \\
\left(3.40^{* *}\right)\end{array}$ & $\begin{array}{c}0.224 \\
(1.736)\end{array}$ & $\begin{array}{c}0.495 \\
(3.19)^{* *}\end{array}$ & $\begin{array}{c}0.3704 \\
(2.354)^{*}\end{array}$ & $\begin{array}{c}0.625 \\
(4.80)^{* *}\end{array}$ & $\begin{array}{c}0.4415 \\
(3.566)^{* *}\end{array}$ \\
\hline $\begin{array}{c}\text { Wage/ } \\
\text { Interest rate }\end{array}$ & $\begin{array}{l}-0.009 \\
(-1.04)\end{array}$ & $\begin{array}{l}-0.016 \\
(-1.66)\end{array}$ & & & & \\
\hline Wages & & & $\begin{array}{l}-0.020 \\
(-0.95)\end{array}$ & $\begin{array}{l}-0.0267 \\
(-1.299)\end{array}$ & & \\
\hline $\begin{array}{l}\text { GDP per } \\
\text { capita }\end{array}$ & & & & & $\begin{array}{l}-0.426 \\
(-2.54)^{*}\end{array}$ & $\begin{array}{c}-0.0433 \\
(-2.563)^{*}\end{array}$ \\
\hline $\begin{array}{l}\text { Technical } \\
\text { change }\end{array}$ & $\begin{array}{c}0.085 \\
(9.659)^{* *}\end{array}$ & $\begin{array}{c}0.077 \\
(8.778)^{* *}\end{array}$ & $\begin{array}{c}0.079 \\
(10.99)^{* *}\end{array}$ & $\begin{array}{c}0.0795 \\
(10.754)^{* *}\end{array}$ & $\begin{array}{c}0.076 \\
(10.99)^{* * *}\end{array}$ & $\begin{array}{c}0.0770 \\
(10.789)^{* *}\end{array}$ \\
\hline $\begin{array}{c}\text { Skill } \\
\text { requirement }\end{array}$ & $\begin{array}{c}0.056 \\
(2.239)^{*}\end{array}$ & $\begin{array}{c}0.053 \\
(1.948)^{* *}\end{array}$ & $\begin{array}{c}0.077 \\
(3.81)^{* *}\end{array}$ & $\begin{array}{c}0.0679 \\
(3.958)^{* *}\end{array}$ & $\begin{array}{c}0.081 \\
(4.02)^{* *}\end{array}$ & $\begin{array}{c}0.0736 \\
(3.5946)^{* *}\end{array}$ \\
\hline Education & $\begin{array}{c}-0.044 \\
(-3.012)^{* *}\end{array}$ & $\begin{array}{l}-0.012 \\
(-0.782)\end{array}$ & $\begin{array}{c}-0.033 \\
(-2.34)^{* *}\end{array}$ & $\begin{array}{l}-0.0005 \\
(-0.040)\end{array}$ & $\begin{array}{c}-0.028 \\
(-2.20)^{* *}\end{array}$ & $\begin{array}{c}0.0042 \\
(0.3664)\end{array}$ \\
\hline NTB & $\begin{array}{l}0.025 \\
(0.56)\end{array}$ & $\begin{array}{c}0.045 \\
(1.0005)\end{array}$ & $\begin{array}{l}-0.056 \\
(-1.71)\end{array}$ & $\begin{array}{l}-0.0272 \\
(-0.991)\end{array}$ & $\begin{array}{l}0.049 \\
(-1.48)\end{array}$ & $\begin{array}{c}-0.0192 \\
(-0.7058)\end{array}$ \\
\hline Tariff & $\begin{array}{l}-0.0019 \\
(-1.051)\end{array}$ & $\begin{array}{l}0.0005 \\
(0.250)\end{array}$ & $\begin{array}{c}-0.004 \\
(-2.61)^{* *}\end{array}$ & $\begin{array}{l}-0.0023 \\
(-1.380)\end{array}$ & $\begin{array}{l}-0.004 \\
(-2.52)^{*}\end{array}$ & $\begin{array}{l}-0.0019 \\
(1.2732)\end{array}$ \\
\hline Adjusted $R^{2}$ & 0.378 & 0.358 & 0.412 & 0.388 & 0.400 & 0.377 \\
\hline$F$-value & 24.12 & 20.67 & 37.16 & 35.33 & 38.71 & 36.81 \\
\hline
\end{tabular}

Number in parenthesis are t-statistics. ${ }^{*}\left({ }^{*}\right)$ indicates significantly different from zero at the .05 level $(.01)$ using a two tailed test 
also used White's method of correcting standard errors in the presence of heteroscedasticity (equations $1 b, 2 b .3 b$ ).

In the equations using the ratio of factor prices (equations $1 \mathrm{a}$ and $1 \mathrm{~b}$ ) the coefficient of the wage/interest rate variable has the expected sign, but is only statistically significant at the $10 \%$ level. Our concern that measured interest rates may not reflect true borrowing costs in some countries due to capital market imperfections led us to use wage levels alone (equations $2 \mathrm{a}$, and $2 \mathrm{~b}$ ). The results retain the expected sign, but the estimated coefficients are still insignificantly different from zero at conventional levels. Using GDP per capita as a proxy for wages also yields results with the expected sign, that are significantly different from zero. To the extent that per-capita GDP is a good proxy for wages, these results imply factor costs affect the choice between new and used capital equipment.

All of the estimated coefficients for the machine specific technology and skill variables have the expected signs and are significantly different from zero at the $.01\left(^{* *}\right)$ level (using a two-tailed test). Indeed, the most striking outcome of the empirical work is the strong and robust performance of the technological and skill-related variables. The proportion of equipment imported second-hand is larger, the more high tech are the machines (as measured by the skill index) and the faster is technological progress (i.e. the larger is depreciation). The rate of technological upgrading was measured as the percentage difference between the unit value of exports of new machines and used machines in each machinery category. The rationale for this method is that the greater 
the improvement in a new model, the greater the drop in the market price of the previous model.

Results on the education variable are as expected and significant in all three versions of the equations estimated using the weighted OLS method, but not in the equations using White's corrected standard errors. The education variable was measured as average years of schooling, and may be too general to capture the extent of technical training. Note that GDP per capita (which is statistically significant with the expected sign when we use White's corrected standard errors) may also partly capture the degree of technological development of a country, thus strengthening our presumption that the absorption capacity is an important element of the choice of technology. ${ }^{6}$

The results for the trade policy variables are somewhat disappointing. The estimated coefficient of the dummy variable for the existence of non-tariff import barriers on used machinery is of inconsistent sign and is never significant. This may be due to incomplete data, because the variable was generated using reports of the existence of NTBs on used machinery in various surveys of trade policy in the countries in the sample, but some of these NTBs may simply not have been reported . The model predicted that tariffs on machinery, by increasing the cost of capital to the firm, would encourage firms to opt for more labor-intensive used machinery. Yet the estimated coefficient of the tariff variable was negative and at times significant.

6 Problems of multicollinearity may emerge, in principle, between the education and the GDP per capita variables. All the same, given the broader meaning og the GDP variable, we have decided to keep both variables in the equation. 
The lack of robustness of wages (when measured directly and not by GDP, which also reflects the absorption capacity) and the unexpected sign on the tariff variable can also be interpreted as an indirect indicator of the importance of including technological factors and skill constraints in the model. Recall that in equation (5), which specifies the price at which firms will be indifferent between new and used machinery, the sign and magnitude of the impact of factor-price and tariff changes depends on the rate of technological change $\left(a_{n} / a_{0}\right)$, adjusted for the decrease in productivity of machines due to age $(\alpha)$ and the "inability coefficient" $(\gamma)$. The apparent lack of significance of the factorprice variables for used machinery demand may be explained by a relatively small value of the inability coefficient $(\gamma)$. The consistently significant results for the GDP variable and the significance of the education variable in at least some of the estimated equations, also buttress the conclusion that technology and skill factors are crucial in determining the choice of type of machinery.

\section{Conclusions}

Developing and transitional economies frequently discriminate against imports of second-hand goods, including production machinery. The literature on this issue has pointed out that restrictions of this kind are costly because they deny firms access to older equipment, which is usually more labor-intensive than new equipment, and thus more appropriate for low-wage countries.

We developed a model that extended the established approach to take into 
consideration technological progress embodied in new machinery and skill constraints faced by firms in developing countries and tested hypotheses based on the model using data on U. S. exports of new and used metalworking machinery by country of destination. The results tend to corroborate the view that used equipment will be demanded by firms in lower-income developing countries. The proportion of each type of machinery bought second-hand is especially high for "higher-tech" equipment requiring more sophisticated operating skills. Econometric tests of the determinants of used machinery trade indicate that the traditional emphasis on factor prices as the determinants of a firm's choice between new and used machinery may be misplaced. Our results reveal the significant role of technological, skill and (to a lesser extent) educational factors in the choice of used versus new machines. Our findings support the hypothesis that the 'absorptive capacity' of a country (the ability to master a new technology) affects the choice of the type and vintage of machines.

The finding that developing countries buy a larger share of old vintage when machines have a fast rate of technological progress may be of some concern because it implies that the technological gap between the North and South is likely to increase, the faster the rate of technological progress. What policy measures can reduce the risk of a growing technology gap?

Our results indicate that trade policy measures such as quantitative restrictions on imports of used machines do not significantly affect the new/used machinery decisions of firms. The traditional criticism of the attempt to upgrade technology by restricting 
imports of used equipment is that such restrictions deny firms access to more appropriate labor-intensive techniques embodied in older vintage machinery. Our model and results indicate that, in addition, such restrictions force firms to buy more expensive new equipment that they may not be able to operate at full efficiency due to skill constraints in the labor force. The policy implication is that instead of imposing restrictions on used machinery imports, countries should concentrate on improving the overall investment environment and their 'absorptive capacity' for new technology by fostering education (particularly technical education) so that they will be able to master new technologies. 


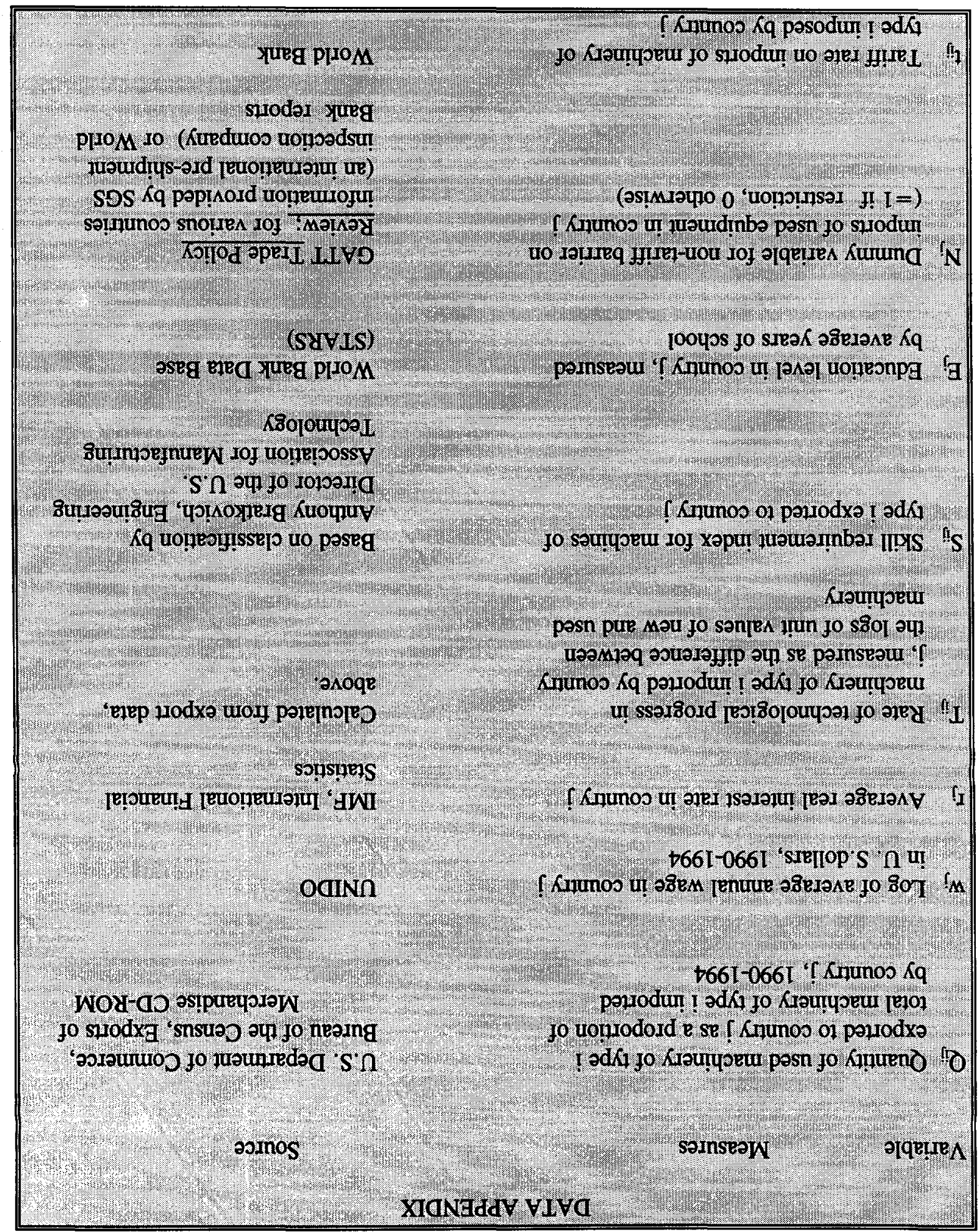




\section{References}

Bardhan, Pranab, 1970, 'Economic Growth, Development and Foreign Trade; a Study in Pure Theory', John Wiley and sons, New York

Benhabib, Jesse and Aldo Rustichini, 1991, 'Vintage Capital Investment and Growth', Journal of Economic Theory, 55, pp. 323-339

Bond, Eric, 1983, 'Trade in Used Equipment with Heterogeneous Firms', Journal of Political Economy, vol. 91, n.4, 688-705

Chari, V.V. and H. Hopenhayn, 1991, 'Vintage Human Capital, Growth and the Diffusion of New Technology', Journal of Political Economy, vol. 99, n.6, pp1142-1965

Dasgupta, P. and J Stiglitz (1988) 'Learning by Doing, Market Structure and Industrial and Trade Policies', Oxford Economic Papers, 40, pp 246-68

David, P., 1993, 'Knowledge, Property and the System Dynamics of Technological Change' in 'Proceedings of the World Bank Annual Conference on Development Economics 1992', The World Bank, Washington DC.

Evenson, Robert and Westphal, Larry, 1994, 'Technological Change and Technology Strategy' in TN Srinivasan and Jere Behrman, eds. 'Handbook of Development Economics', Vol. 3, North Hollans

Gabisch, Gunter, 1975, 'A Vintage Capital Model of International Trade: the Case of Trade with Second Hand Machines', Journal of International Economics, , 5, pp.365-383

Grant, James and Len Nichols, 1986, 'On the Existence of a Market for Second Hand Physical Capital: an Empirical Test of the Keynesian and Neoclassical Assumptions', Journal of Macroeconomics Vol 8, n.2, pp131-157

James, Dilmus, 1974, 'Used Machinery and Economic Development', 1984, MSU International Business and Economic Studies, Michigan State University, East Lansing.

James, Dilmus, 1975, 'Second Hand Machinery in Development: a Comment', The Journal of Development Studies, vol. 11, n. 3, pp. 230-233

Jovanovic Boyan and Glenn MacDonald, 1993, 'Competitive Diffusion, NBER Working Paper n.4463

Jovanovic, Boyan and Yaw Nyarko, 1995, 'The Transfer of Human Capital', Journal of Economic Dynamics and Control', 19, June, pp. 1033-1064.

Jovanovic, Boyan and Yaw Nyarko, 1996, How does Productivity Depends on Past R\&D?', Fondazione Eni Enrico Mattei, Note di Lavoro, forthcoming.

Keller, Wolfgang, 1994, 'Absorptive Capacity: Understanding the Creation and Acquisition of 
Technology in Development', Department of Economics, Yale University, mimeo

Kravis, Irving B. And Robert Lipsey, 1982, 'Prices and Market Shares in the International Machinery Trade', The Review of Economics and Statistics, vol. 64, n1, pp110-116

Lall, S.,1987, 'Learning to Industrialise. The Acquisition of Technological Capabilities in India', Macmillan, London

Mainwaring, L., 1986, 'International Trade in New and Used Machines', Cambridge Journal of Economics, 10 , pp 247-263

Oliner, Stephen, D., 1993, 'New Evidence on the Retirement and Depreciation of Machine Tools', Board of the Federal Reserve System, Working Paper Series n.147, December

Pack, Howard and Michael Todaro, 1970, 'Industrialization, Employment and the Choice of Alternative Vintage Equipment in Less Developed Countries' Economic Growth Center, Yale University, Center Discussion Paper n.5

Pack, Howard, 1978, 'The Optimality of Used Equipment: Calculation for the Cotton-Textile Industry', Economic Development and Cultural Change, vol. 26, n.2, 307-325

Schuette, H.L., 1994, 'Vintage Capital, Market Structure and Productivity in an Evolutionary Model of Industry Growth', Journal of Evolutionary Economics, Vol. 4, n. 3, pp173184

Schwartz, Sandra, 1973, 'Second hand Machinery in Development or How to Recognize a Bargain', Journal of Development Studies, vol. 9 n. 4, pp544-555

Sen, Amartya K., 1962, 'On the Usefulness of Used Machines', The Review of Economics and Statistics, vol. 44, n.3, pp346-348

Smith, M.A.M, 1974, 'International Trade in Second Hand Machines', Journal of Development Economics, vol. 1, n.3, pp261-278

Smith, M.A.M, 1976, 'International Trade Theory in Vintage Models', The Review of Economic Studies v.43, pp. 99-113

Swan, Peter, 1972, 'Optimal Durability, Second Hand Markets and Planned Obsolescence', The Journal of Political Economy, vol. 80, pp575-585

Thoumi, F., 1975, 'Theory of the Optimum Age to Import a Durable Good', Journal of Deveiopment Economics, vol. 2, pp145-160

Williams, M. And J.K. Kwon, 1982, 'Substitution of Equipment, Structures and Labor in South Korea's Manufacturing Industry', Applied Economics, 14, 391-400 


\section{Policy Research Working Paper Series}

Title

WPS1897 Development of Natural Gas and Pipeline Capacity Markets in the United States

WPS1898 Does Membership in a Regional Preferential Trade Arrangement Make a Country More or Less Protectionist?

WPS1899 Determinants of Emerging Market Bond Spread: Do Economic Fundamentals Matter?

WPS1900 Determinants of Commercial Barik Interest Margins and Profitability: Some International Evidence

WPS1901 Reaching Poor Areas in a Federal System

WPS1902 When Economic Reform is Faster than Statistical Reform: Measuring and Explaining Inequality in Rural China

WPS1903 Taxing Capital Income in Hungary and the European Union

WPS1304 Ecuador's Rural Nonfarm Sector as a Route Out of Poverty

WPS1905 Child Labor in Côte d'Ivoire: Incidence and Determinants

WPS1906 Developing Countries' Participation in the World Trade Organization

WPS1907 Development Expenditures and the Local Financing Constraint

WPS1908 How Dirty Are "Quick and Dirfy" Methods of Project Appraisal?

WPS1909 Capital Market Responses to Environmental Performance in Developing Countries

WPS1910 Capital Outflow from the Agriculture Sector in Thailand
Author

Andrej Juris

Faezeh Foroutan

Hong G. Min

Asli Demirgüç-Kunt

Harry Huizinga

P. Sintim-Aboagye

Martin Ravallion

Martin Ravallion

Shaohua Chen

Jean-Jacques Dethier

Christoph John

Peter Lanjolww

Christiaan Grootaert

Constantine Michalopoulos March 1998

Albert D. K. Agbonyitor

Dominique van de Walle

Dileni Gunewardena

Susmita Dasgupta

Benôit Laplante

Nlandu Mamingi

Junichi Yamada
March 1998

March 1998

March 1998

E. On

33410

March 1998 37656

March 1998

March 1998

March 1998

March 1998

April 1998

April 1998

April 1998

Contact

for paper

S. Vivas

82809

L. Tabada

36896

P. Sader

33902

P. Sader 33902

J. Smith

87215

$P$. Lanjouw 34529

G. Ochieng 31123

L. Tabada 36896

L. James

35621

C. Bernardo 31148

Aprii 1998

R. Yazigi 37176

E. Khine

37471 


\section{Author}

Stijn Claessens Tom Glaessner

Deon Filmer Margaret Grosh Elizabeth King Dominique van de Walle
Tiste

WPS1911 The Internationalization of Financial Services in Asia

WPS1912 Pay and Grade Differentials at the World Eank

\section{Date}

April 1998

April 1998

\section{Oya Celasun}

WPS1914 Distinguishing between Types of
Data and Miethods of Collecting Them

WPS1915 Distortionary Effects of State Trading in Agriculture: Issues for the Next Round of Multilateral Trade Negotiations

WPs1916 The Size, Origins, and Character of Mongolia's Informal Sector during the Transition

WPS1917 Financial Liberalization and Financial Asli Demirgüç-Kunt Fragility

WPS1918 How Does Foraign Entry Affect the Dornestic Banking Market?

WPS1919 The Emoirical Effects of Performance Mary Shirley Contracts: Evidence from China

WPS1920 Education and Earnings in a Transition Economy (Vietnam)
Jesko Hentschel Enrica Detragiache

$$
\begin{aligned}
& \text { Stijn Claessens } \\
& \text { Asli Demirgüç-Kunt } \\
& \text { Harry Huizinga }
\end{aligned}
$$
Lixin Colin $X u$

April 1998

April 1998

April 1998

Francis $\mathrm{Ng}$

James H. Anderson

May 1998

May 1998

May 1998

May 1998

May 1988 Harry Anthony Patrinos Meera Venkataraman
Contact

for paper

R. Vo

33722

C. Bernardo

31148

K. Labrie 31001

PREM Advisory 87736

M. Fernandez 33766

P. Sintim-Aboagye 37656

P. Sintim-Aboagye 37656

R. Vo

33722

$P$. Sintim-Aboagye 38526

M. Christian 36736

May 1998 on Bangalore's Public Service

Soamiely Andriamananjara May 1998 Maurice Schiff
C. Bernardo 31148

ᄂ. Tabada 36896 